\title{
The Import of Southern
}

\section{Criminology:}

\section{Post-Colonialism Trumps the Defiance of Universalism}

\section{Ana Paula Zimmermann de Meireles Philippi \\ MSc in Criminology and Criminal Justice, University of Edinburgh}

\begin{abstract}
Southern Criminology is a post-colonial movement of knowledge production that has political, empirical and theoretical facades. This article argues that the most significant characteristic of Southern Criminology is the highlighting of the everlasting criminogenic effects of colonialism. It challenges the suggestion made by Roger Matthews, in his paper "False starts, wrong turns and dead ends: Reflections of recent developments in Criminology," that the greatest import of such a movement is the defiance of universalism of the theories of the Global North. It does so by examining the concepts of Southern Criminology, the risks of recognising the defiance of universalism as its main output and the potentialities of recognising its post-colonial characteristics for the advancement of theoretical criminology both in the Global South and the Global North.
\end{abstract}

Keywords: Southern criminology, universalism, post-colonialism, criminological knowledge building, defying northern hegemony 


\section{Introduction}

In the paper "False starts, wrong turns and dead ends: Reflections of recent developments in Criminology," Roger Matthews states that the primary significance of Southern Criminology has been to defy the allegation of universalism of the criminological theories from the Global North. ${ }^{1}$ Roger's article reflects on the "decline in substantial theoretical contributions" over the last couple of decades ${ }^{2}$ and the "political and cultural reductionism" of some scholars for developing new theories. ${ }^{3}$ It also discusses how criminologists have refrained from providing causal explanations to the phenomena in favour of description and statistical analysis, as well as disregarded class dynamics in inquiry. Finally, it considers the import of victimisation for the study of crime. On what is precisely important for this article, Roger touches upon what he calls "theoretical discussions," such as cultural criminology, green criminology, feminist criminology, and, amongst others, Southern Criminology.

Matthews does not conduct his analysis in a way that allows him to reflect extensively on what these theoretical discussions are per se; the focus of the paper is of another nature. However, given his mention of Southern Criminology as "the most significant theoretical development in the recent period," 4 it becomes crucial that its relevance is discussed.

Particularly, it is vital to understand the importance of Southern Criminology's attempt to bring the ongoing effects of colonisation to matters of crime and punishment. To do so, this essay will explore the concept of "Southern Criminology" and what we are referring to when we name South and North. It will then detail why defying universalism is not the most meaningful output of Southern Criminology and why the unveiling of colonialism is. Finally, it will debate the implications of considering colonialism as an indisputable criminological

\footnotetext{
${ }^{1}$ Roger Matthews, "False Starts, Wrong Turns and Dead Ends: Reflections on Recent Developments in Criminology," Critical Criminology 25, no. 4 (2017): 581, https://doi.org/10.1007/s10612-017-9372-9.

${ }^{2}$ Matthews, 579.

${ }^{3}$ Matthews, 581, mentioning David Garland, The Culture of Control (Oxford: Oxford University Press, 2001); John Pratt, Penal Populism (London: Routledge, 2007); David A. Green, "Feeding Wolves: Punitiveness and Culture," European Journal of Criminology 6, no. 6 (2009), https://doi.org/10.1177/1477370809341227; David Indermaur, "What Can We Do to Engender a More Rational and Less Punitive Crime Policy?," European Journal of Criminal Policy and Research 15, no. 1-2 (2009), https://doi.org/10.1007/s10610-0089096-1; Jonathan Simon, "Entitlement to Cruelty: Neo-Liberalism and the Punitive Mentality in the United States," in Crime, Risk and Justice, eds. Kevin Stenson and Robert R. Sullivan (Coullompton, Devon: Willan Publishing, 2001); and Loïc Wacquant, "Ordering Insecurity: Social Polarization and the Punitive Upsurge," Radical Philosophy Review 11, no. 1 (2008), https://doi.org/10.5840/radphilrev20081112.

${ }^{4}$ Matthews, "False Starts," 581.
} 
topic for the development of criminological theory in the $21^{\text {st }}$ century and attest to the possible political potentials of Southern Criminology's advancement.

\section{Southern Criminology and Conceptualising the South and the North}

Southern Criminology can be described as a theoretical project which seeks to adequately clarify "patterns of crime, violence and justice" ${ }^{5}$ in formerly colonised countries and other places where the production of knowledge was historically undermined. By modifying the perspective for analysis and reclaiming narratives that are entrenched in the colonial history, it also works as an empirical endeavour, attempting to transform the area of knowledge into a more comprehensive one. Another way of representing Southern Criminology is as a political project that hopes to connect international estrangements and democratise what is understood as "knowledge."

One might comprehend all these concepts by seeing Southern Criminology as a postcolonial movement of knowledge production that has political, empirical and theoretical facades. Furthermore, it is a movement that arises from places and communities whose voices were ignored, not to say silenced, throughout the main history of the criminological discipline. These overlooked places and communities are referred to as the Global South, because of the bone-crushing underdevelopment still plaguing the majority of the areas geographically situated on the South of the globe. ${ }^{7}$ Clear examples of such areas are some places in Latin America and Africa. The former for being home to generations of marginalised groups of people. ${ }^{8}$ The latter for the complete dependency on other continents to which it was subjected ${ }^{9}$ that left the region shattered in consequence of the everlasting loss of sovereignty. ${ }^{10}$ Nevertheless, there are communities that are also included in the concept of Global South, even

\footnotetext{
${ }^{5}$ Kerry Carrington, Russell Hogg, and Máximo Sozzo, "Southern Criminology," The British Journal of Criminology 56, no. 1 (2016): 15, https://doi.org/10.1093/bjc/azv083.

${ }^{6}$ Carrington, 15.

${ }^{7}$ Carrington, 6.

${ }^{8}$ Eugenio Raúl Zaffaroni, Criminología: Aproximación Desde un Margen (Bogotá: Editorial Temis S.A., 1988), 76.

${ }^{9}$ Rodrigo Codino, "Por Uma Outra Criminologia Do Terceiro Mundo: Perspectivas da Criminologia Crítica no Sul [For Another Third World Criminology: Perspectives from the South's Critical Criminology]," Revista Liberdades, no. 20 (September/December 2015): 30, https://www.ibccrim.org.br/publicacoes/edicoes/462/7428.

${ }^{10}$ Biko Agozino, "Imperialism, Crime and Criminology: Towards the Decolonisation of Criminology," Crime, Law and Social Change 41, no. 4 (2004): 347, https://doi.org/10.1023/B:CRIS.0000025766.99876.4c.
} 
though they are objectively located in countries in the North or within other countries, which can be considered part of the Global North. For instance, Native Americans, in the United States of America and Canada, ${ }^{11}$ and Indigenous Australians. ${ }^{12}$ These groups of people are more related to the Global South than to the Global North, because, in the context of knowledge production and power control, they have been often overpowered and silenced. ${ }^{13}$ In this sense, the Global South stands for an analogy of the periphery, of the inferior and the different, whilst the Global North is often perceived as the standard, which everyone else supposedly wishes to achieve. ${ }^{14}$ Thus, the divisions between the Global North and South are not steady, ${ }^{15}$ since it is clear that we can find aspects of the South within the North and vice-versa. ${ }^{16}$

\section{The Most Important Output of Southern Criminology}

One of the products of Southern Criminology is its opposition to the universalism claimed by Northern theories, as mentioned by Matthews, ${ }^{17}$ but this is not its primary output. Universalism is a belief that there are objective "universal values" which can explain particular events. ${ }^{18}$ For example, one of the universalised social science assumptions, pushed by the Global North, was that a "strong central state" is imperative for preventing the horrors of civil war. ${ }^{19}$

Being one of the main characteristics of social science from the Global North, ${ }^{20}$ universalism is responsible for establishing a standard according to which Western Europe and

\footnotetext{
${ }^{11}$ Elaine Fishwick and Marinella Marmo, "Criminology in Australia: A Global South Perspective," in The Handbook of the History and Philosophy of Criminology, ed. Ruth Ann Triplett (Hoboken, NJ: WileyBlackwell, 2018), https://doi.org/10.1002/9781119011385.ch19.

${ }^{12}$ Kerry Carrington and Russell Hogg, "Deconstructing Criminology's Origin Stories," Asian Journal of Criminology 12, no. 3 (2017), https://doi.org/10.1007/s11417-017-9248-7.

${ }^{13}$ Barret Weber and Rob Shields, "The Virtual North: On the Boundaries of Sovereignty," Ethnic and Racial Studies 34, no. 1 (2011), https://doi.org/10.1080/01419870.2010.490592.

${ }^{14}$ Carrington, Hogg, and Sozzo, "Southern Criminology," 5.

${ }^{15}$ Katja Franko Aas, “"The Earth Is One but the World Is Not': Criminological Theory and Its Geopolitical Divisions," Theoretical Criminology 16, no. 1 (2012): 14, https://doi.org/10.1177/1362480611433433; Carrington and Hogg, “Deconstructing Criminology’s Origin Stories," 183.

${ }^{16}$ Carrington, Hogg, and Sozzo, "Southern Criminology," 3.

${ }^{17}$ Matthews, "False Starts."

${ }^{18}$ Walter D. Mignolo, "The Geopolitics of Knowledge and the Colonial Difference," South Atlantic Quarterly 101, no. 1 (2002), https://doi.org/10.1215/00382876-101-1-57.

${ }^{19}$ Carrington and Hogg, "Deconstructing Criminology's Origin Stories," 188.

${ }^{20}$ Aas, “"The Earth Is One, ", 7.
} 
North America are the only legitimate sources of knowledge. ${ }^{21}$ This approach also downgrades cultural and legal products from the Global South, ${ }^{22}$ which, in contrast to the scholarly development of the North, is perceived as being unorthodox and less methodical. ${ }^{23}$ In the Global South, knowledge production is further complicated by the lack of theoretical and informational support and the shortage of objectivity, which is due to scholars' profound relation to the observed phenomena. ${ }^{24}$

The problem with seeing "the defiance of universalism" as the principal output of Southern Criminology is that it might suggest that scholars from the Global North may overcome it by digging into the Global South as a site of inquiry. Such a view would keep the Global South as a "data mine," 25 even if analysed with a different mind-set. It also does not break with the "linear narrative" 26 of knowledge production, according to which every world experience is capable of "evolving" to arrive at some kind of modern and European civilisation. On this account, defying universalism would only imply "opening social sciences" 27 to work in a different way, but that is also not sufficient.

Conversely, Southern Criminology does not only aspire to make further comments and inclusions to the ever-growing inventory of "criminologies," 28 which would happen if the mentioned scenario were to occur. Criminology produced in the Global South is instead an emancipation operation. ${ }^{29}$ It questions what the penal system is, what are its effects and its connections to the systems of control and power. Furthermore, it acknowledges that all the central answers were formulated ignoring the specificities of the margins. ${ }^{30}$ By doing this, Southern Criminology hopes to find which criminological expertise is relevant to transform

\footnotetext{
${ }^{21}$ Codino, "Por Uma Outra Criminologia," 26.

${ }^{22}$ Chris Cunneen, "Postcolonial Perspectives for Criminology," in What Is Criminology?, ed. Mary Bosworth and Carolyn Hoyle (Oxford: Oxford University Press, 2011), 261, https://doi.org/10.1093/acprof:oso/9780199571826.003.0018.

${ }^{23}$ Zaffaroni, Criminología, 4.

${ }^{24}$ Zaffaroni, 4.

${ }^{25}$ Carrington, Hogg, and Sozzo, "Southern Criminology," 2.

${ }^{26}$ Mignolo, "The Geopolitics of Knowledge," 88.

${ }^{27}$ Mignolo, 73.

${ }^{28}$ Carrington and Hogg, "Deconstructing Criminology's Origin Stories," 185.

${ }^{29}$ Carrington and Hogg, 185.

${ }^{30}$ Zaffaroni, Criminología, 19.
} 
lives in the periphery and support people in those various peripheries to reveal all their capacities. $^{31}$

On this view, the main import of Southern Criminology is that it highlights the criminological effects of colonialism and the way this knowledge empowers those Southern communities and nations.

Despite the development of this knowledge, Northern criminological theorists still broadly ignore that the rise of criminology as a field coincides with the climax of colonial dominance. ${ }^{32}$ Not to mention that, throughout its history, central criminology, that is the criminological knowledge produced in countries of the Global North, devoted fewer endeavours in understanding and solving the consequences of enslavement and indigenous genocide than it did to "street robbery." 33 Contemporary figures on the overrepresentation of minorities in the criminal justice system exemplify the connection of the system to the continuous pauperism of "formerly enslaved people." ${ }^{34}$ Even so, the effects of enslavement are not sufficiently explored in mainstream criminology.

Scholars of mainstream criminology keep attempting to interpret and solve urban violence whilst ignoring colonial violence and the events that made the world as it is, ${ }^{35}$ even though the latter had probably far more profound consequences for current trends in crime and crime control than the former. Focusing on aspects of crime in a peaceful internal context was another way of dismissing colonialism's criminological effects. ${ }^{36}$ This lens of criminology was unsuccessful in developing relevant conclusions about the massacre and annihilation of entire societies that has made the world as we know it. ${ }^{37}$

${ }^{31}$ Zaffaroni, 19.

${ }^{32}$ Agozino, "Imperialism, Crime and Criminology," 349.

${ }^{33}$ Maureen Cain, "Counter-Colonial Criminology: A Critique of Imperialist Reason by B. Agozino," The Howard Journal of Criminal Justice 46, no. 5 (2007): 535, https://doi.org/10.1111/j.14682311.2007.00499.x.

${ }^{34}$ Cunneen, "Postcolonial Perspectives for Criminology," 250-251.

${ }^{35}$ Carrington, Hogg, and Sozzo, "Southern Criminology," 8.

${ }^{36}$ Carrington and Hogg, "Deconstructing Criminology's Origin Stories," 188.

${ }^{37}$ Carrington, Hogg, and Sozzo, "Southern Criminology," 2. 
From a central perspective, the enterprise of colonisation and imperialism seems to be more of a topic for international law and economic development than criminological interest. On the other hand, for the Global South, it is at the very core of its foundation as nation-states, and at the core of the evolution of its systems of "justice" and social control. Therefore, criminology anywhere cannot go ahead without considering the criminogenic consequences of colonialism.

Southern Criminology prevents the further growth of this "collective amnesia." ${ }^{\text {" I }}$ It forces a scholarly dialogue about why some forms of violence, such as state violence and collective brutality against entire groups of people, were and are still legitimated.$^{39}$ Likewise, it obliges both colonised countries and colonisers to recognise that colonialism is not something in the past, but a remaining process that demands theorisation from criminology. ${ }^{40}$

This phenomenon becomes transparent when we analyse patterns of incarceration and overrepresentation of certain groups in the criminal justice system. On this account, it is well known that the representation of indigenous people and formerly enslaved minorities in the criminal justice systems of formerly colonised countries is considerably high. ${ }^{41}$

Besides highlighting the perception of state crime, considering colonialism when interpreting crime and social control also allows for a better consciousness of how public bodies perform criminal justice in colonised nations and how minorities might not legitimise such a performance and see it as wrongful. ${ }^{42}$

Southern Criminology brings to light that criminological knowledge was one of the scientific foundations that legitimised the invasion and exploitation of the broadly understood Global South by northern nation-states. For this reason, criminology has been previously termed "an imperialist science." 43 For example, whilst severe punishments were questioned in

\footnotetext{
${ }^{38}$ Willie Henderson, "Metaphors, Narrative and 'Truth': South Africa's TRC," African Affairs 99, no. 396 (2000): 457, https://doi.org/10.1093/afraf/99.396.457.

${ }^{39}$ Cain, "Counter-Colonial Criminology," 536.

${ }^{40}$ Cunneen, "Postcolonial Perspectives for Criminology," 249.

${ }^{41}$ Carrington and Hogg, "Deconstructing Criminology's Origin Stories," 191.

${ }^{42}$ Cunneen, "Postcolonial Perspectives for Criminology," 254.

${ }^{43}$ Agozino, "Imperialism, Crime and Criminology," 344.
} 
Europe, in the 18th century, this wisdom was not spread to favour Africans exploited by slave trade during colonial rule. ${ }^{44}$

To illustrate the relevance of bringing the topic of colonisation to criminological theorising, it is important to remember that mainstream criminology for a long time, and some might say even today, connected criminality to characteristics that are common to the Global South. Lombroso, one of the founding fathers of traditional criminology, characterised Asian and African exhibits as examples of underdevelopment, an idea that still finds followers in this century's criminological field. ${ }^{45}$ More recently, a belief has arisen that societal disorder generates criminal behaviour. ${ }^{46}$ This is explicit in Wilson and Kelling's "Broken Window Theory," ${ }^{47}$ which links societal disorder to impunity, due to a general acquiescence to "incivilities and infractions." ${ }^{48}$ Such a conceptualisation might seem neutral at first, but what Northern theorists deemed uncivil and disorderly is remarkably similar to Southern ways of living and infrastructure, which once again might serve to explain crime trends in the Global South as predetermined by its "unfitness" to Northern standards. Be it for religious, civic or scientific reasons, the Global North has frequently generated new logics for considering phenomena categorised as "different", which generally coincided with those occurring in the South. The North often translated "different" phenomena or cultures as second-rate, vicious, oppressed by tyrants or extremist. ${ }^{49}$ This conceptualisation, which defined the "Other" as second-rate, was fundamental for the colonial enterprise. It generated the supposed necessity for "civilising," but also helped to establish who was decent and law-abiding, ${ }^{50}$ which unsurprisingly usually coincided with the residents of colonising nations.

${ }^{44}$ Agozino, 346.

${ }^{45}$ Carrington and Hogg, "Deconstructing Criminology's Origin Stories," 186.

${ }^{46}$ Carrington and Hogg, 188.

${ }^{47}$ James Q. Wilson and George L. Kelling, "Broken Windows: The Police and Neighborhood Safety," The Atlantic Monthly 249, no. 3 (1982), https://www.semanticscholar.org/paper/BROKEN-WINDOWS\%3ATHE-POLICE-AND-NEIGHBOURHOOD-SAFETY-WilsonKelling/afac4ce61a0a68b81964a29efccb3cf4b81f2ff9.

${ }^{48}$ Stefano Bloch, "Broken Windows Ideology and the (Mis)Reading of Graffiti," Critical Criminology 28, no. 4 (2020): 707-708, https://doi.org/10.1007/s10612-019-09444-w.

${ }^{49}$ Zaffaroni, Criminología, 76.

${ }^{50}$ Cunneen, "Postcolonial Perspectives for Criminology," 261. 
After acknowledging these underlying truths, it takes little reasoning to understand why the Global South receives classical criminological knowledge with scepticism. It becomes even more evident considering that this knowledge departs from the promise of internal stability that was achieved in coloniser states by the intimidation of the colonised territories ${ }^{51}$ and the fact that such peace never existed in colonised countries which were founded through state violence. ${ }^{52}$ In a general sense, the Global South had a history of dominance and violence as the foundation for criminological knowledge production, in a way that scholarship centred on "shattered gardens" as the subject matter, whilst the North centred on "appealing gardens."

Still, it is not necessarily the fact that post-colonialism should be understood only as an insubordinate or insurgent project, as it has been by some. ${ }^{54}$ It should not be ignored that, regularly, the post-colonial theory is distinguished from Southern Criminology because it tends to sentimentalise indigeneity. ${ }^{55}$ However, it is arguable that the post-colonial aspect of Southern Criminology, as its primary output, allows a process of recognition by the Global South to unveil all its potentialities, a process which is not possible without a full understanding of colonisation.

\section{The Implications of Considering Colonialism an Indisputable Subject for Criminology on the Development of Criminological Theory in the $21^{\text {st }}$ Century}

By bringing to light the still aching scars of colonisation, Southern Criminology opens up the path for the appreciation of nations of the Global South. It highlights what makes them what they are and how they can promote peace within their communities. Furthermore, it allows for the emergence of solutions that reflect their histories and singularities, instead of simply perpetuating imported ones.

However, the path for achieving this is not yet paved.

\footnotetext{
${ }^{51}$ Zaffaroni, Criminología, 216.

52 Carrington, Hogg, and Sozzo, "Southern Criminology," 3.

${ }^{53}$ Codino, "Por Uma Outra Criminologia," 30.

${ }^{54}$ Carrington, Hogg, and Sozzo, "Southern Criminology," 2.

${ }^{55}$ Carrington and Hogg, "Deconstructing Criminology’s Origin Stories," 194.
} 
The leading schools of criminological knowledge remain in the Global North, notably in Anglophone countries, ${ }^{56}$ whilst there is a notable lack of specific university courses in criminology in countries of the South. ${ }^{57}$ Unsurprisingly, theorists from the South are rarely read or praised in the North and African, Latin-American, Asian and arguably, to some extent, Australian scholarship does not stand in a place of significance as compared with Northern scholarship. ${ }^{58}$ Furthermore, there is minimal opportunity for the many peripheral communities that share a history of domination to engage in criminological debate. Instead, communities such as these usually connect through the intermediation of the North. ${ }^{59}$

Also, when regarding Asia and the Pacific, ${ }^{60}$ the variety of spoken languages limits the possibility for knowledge exchange. It has been suggested that, perhaps the so-called "Third World," a term that was coined after World War II to refer to impoverished Africa, Asia and Latin-America, ${ }^{61}$ did not establish a criminological scholarship of their own because of the absence of applicability of the mainstream knowledge to their experiences. ${ }^{62}$ On the other hand, it is undeniable that throughout the colonial enterprise, it was not only political and economic institutions imposed on the Global South but also educational and intellectual systems leading to a scholarship dependency. ${ }^{63}$ This imposition, undeniably, also impedes the establishment of a Southern-specific scholarship, since it first demands emancipation from imposed intellectuality.

It must be stated that this movement is not about idealising the production of knowledge in the South. ${ }^{64}$ Southern Criminology is not a set of consolidated beliefs, nor are Southern criminologists unaffected by existent theories and dominant influences. ${ }^{65}$ Still, listening to the

${ }^{56}$ Aas, “"The Earth Is One,"” 6.

${ }^{57}$ Agozino, "Imperialism, Crime and Criminology," 343.

${ }^{58}$ Kerry Carrington, "Book Review: Southern Theory: The Global Dynamics of Knowledge in the Social Sciences by Raewyn Connell,” Journal of Sociology 44, no. 3 (2008): 301, https://doi.org/10.1177/1440783308092886.

${ }^{59}$ Zaffaroni, Criminología, 3.

${ }^{60}$ John Braithwaite, "Rethinking Criminology Through Radical Diversity in Asian Reconciliation," Asian Journal of Criminology 10, no. 3 (2015): 183, https://doi.org/10.1007/s11417-014-9200-z.

${ }^{61}$ Arturo Escobar, Encountering Development: The Making and Unmaking of the Third World (Princeton: Princeton University Press, 2011), https://doi.org/10.2307/3034652.

62 Agozino, "Imperialism, Crime and Criminology," 351.

${ }^{63}$ Mignolo, "The Geopolitics of Knowledge," 63.

${ }^{64}$ Carrington, Hogg, and Sozzo, "Southern Criminology," 2.

${ }^{65}$ Aas, "'The Earth Is One,"” 16. 
criminologists of the South is a bet on avoiding the rejection of any knowledge's analytical aspect. $^{66}$

To avoid solely relying on the use of Northern theory, Southern Criminology aims to create its own. ${ }^{67}$ Perhaps, not a theory of answers, since the discipline of criminology in the margins is filled with doubts and questions that do not necessarily arise from the academia, but from daily experiences and hardships. ${ }^{68}$ Instead, it focuses on essential factors of political life, bringing to light the control inflicted on the Global South through the authoritarian dominance of determinate families and groups throughout history. ${ }^{69}$

In this sense, criminologists from the centre, or those with a Northern perspective, can also learn from Southern scholars, notably about the experiences of those living in the margins. ${ }^{70}$ Additionally, when the ruinous effects of the enterprise of colonisation are recognised and vastly acknowledged, the assumption that the world must rely on countries of the Global North as the conveyors of how to understand and deal with crime and social control, will not stand. ${ }^{71}$ Not to mention that it would no longer be viable to ignore human rights crimes as such issues are indeed worthy of criminological inquiry. ${ }^{72}$

Additionally, the rise of a Southern criminological scholarship would favour finding new approaches for dealing with crime. ${ }^{73}$ Viewed in this way, the Global North would also have the opportunity to take advantage of this endeavour, as it would provide inspiration for innovation and new concepts and programmes of inquiry reflected by the events in the Global South. ${ }^{74}$ Moreover, the recognition of the legacies of colonisation would provide Northern countries with a deeper and more holistic understanding of current issues within their own criminal justice systems, like the overrepresentation of racial minorities. ${ }^{75}$

\footnotetext{
${ }^{66}$ Aas, 16.

${ }^{67}$ Carrington and Hogg, "Deconstructing Criminology’s Origin Stories," 185.

${ }^{68}$ Zaffaroni, Criminología, 2.

${ }^{69}$ Codino, "Por Uma Outra Criminologia," 23.

${ }^{70}$ Agozino, "Imperialism, Crime and Criminology."

${ }^{71}$ Agozino, 356.

72 Agozino, 355.

73 Agozino, 353.

${ }^{74}$ Carrington and Hogg, "Deconstructing Criminology's Origin Stories," 194.

${ }^{75}$ Carrington and Hogg, 194.
} 
From a more peripheral standpoint, Southern Criminology must aim to dismantle and reassemble criminology from its roots. ${ }^{76}$ In this sense, it must be recognised that there are various sources of criminological knowledge. ${ }^{77}$ For that matter, some of the "innovative" products of Southern Criminology simply reflect traditional solutions of peripheral communities that were earlier ignored by imposing colonial powers. An example of this is the practice of restorative justice, ${ }^{78}$ which has strong connections with ancient Confucian philosophical ideas. ${ }^{79}$

Compared to the central or Northern context, the integration of supposed unorthodox perspectives from peripheral nations and communities, significantly allows for the potential combination of more contemporary and traditional knowledge sets. ${ }^{80}$ This merger balances the weaknesses and advantages of each source. ${ }^{81} \mathrm{~A}$ criminological movement from the South would reflect its cultural diversity, allowing for creative responses to arise. ${ }^{82}$

\section{Political Potentials of the Advancement of Southern Criminology}

More than contributing to criminology's theoretical development in the $21^{\text {st }}$ century, the advancement of post-colonial Southern Criminology has the potential to strengthen legitimacy and sovereignty of the countries comprising the Global South. As Max Weber stated, "a state is a human community that (successfully) claims the monopoly of the legitimate use of physical force within a given territory." 83 On the other hand, social contract theorists professed that the provision of security was the sole purpose of forming nation-states. ${ }^{84}$ These presumptions are part of a concept established in the Global North, more specifically in Europe. Still, the

\footnotetext{
${ }^{76}$ Carrington and Hogg, 185.

${ }^{77}$ Carrington and Hogg, 185.

78 Jianhong Liu, “Asian Criminology - Challenges, Opportunities, and Directions," Asian Journal of Criminology 4, no. 1 (2009): 7, https://doi.org/10.1007/s11417-009-9066-7.

${ }^{79}$ Jianhong Liu, "Principles of Restorative Justice and Confucian Philosophy in China," Newsletter of the European Forum for Restorative Justice 8, no. 1 (2007), https://www.researchgate.net/publication/285055041_Principles_of_Restorative_Justice_and_Confucius_Philos ophy_in_China.

${ }^{80}$ Braithwaite, "Rethinking Criminology," 184.

${ }^{81}$ Braithwaite, 188.

${ }^{82}$ Zaffaroni, Criminología, 95.

${ }^{83}$ Max Weber et al., From Max Weber: Essays in Sociology (New York: Routledge, 2009), 78 https://doi.org/10.4324/9780203452196.

${ }^{84}$ Melissa M. Lee, Gregor Walter-Drop, and John Wiesel, "Taking the State (Back) Out? Statehood and the Delivery of Collective Goods," Governance 27, no. 4 (2014): 636, https://doi.org/10.1111/gove.12069.
} 
monopoly of force and the provision of safety as the foundations for the nation-state were imposed on the Global South, and they are yet to be adjusted to align with local realities. This mismatch between state-founding theories and local experience is where Southern Criminology's theoretical advancement can play its most significant role.

The history of domination and violence previously mentioned left a legacy of disconnection between the people of the Global South and their states, which unsurprisingly harms the existence of republics themselves. ${ }^{85}$ Criminal justice systems were assumed legitimate from a positivist perspective, even though opinions on this matter from the local population's relevant segments, such as indigenous groups, were solemnly ignored ${ }^{86}$

For a state and its security system to endure, its people must legitimate it. ${ }^{87}$ By analysing recent state-building movements in "non-liberal" nations, Jackson brings to the surface relevant insights that are entirely applicable to the Global South's history with colonialism. Mainly, he refers to the risk of creating "empty-shells" when a state is built without significant legitimacy to the broad public and works solely in favour of a privileged group of people. ${ }^{88}$ It takes little understanding of the Global South's reality to note that the hollow foundations of many states with illegitimate criminal justice systems are a consequence of the establishments of colonial rule.

In this sense, Southern Criminology as a political movement can work to dislodge the foundations of local criminal justice systems that do not represent the interests of Southern populations; simultaneously, it has the capability to translate regional praxis into policy. For example, state sovereignty, understood as the capability of dictating or even influencing the social order in a territory, is a challengeable concept under a post-colonial perspective. First, because it is not globally endorsed. Second, it has direct effects on how criminological ideas of punitiveness, safety and deviance are understood ${ }^{89}$ From a post-colonial standpoint, when

\footnotetext{
${ }^{85}$ Justin Mueller, "Temporality, Sovereignty, and Imperialism: When is Imperialism?," Politics 36, no. 4 (2016): 431, https://doi.org/10.1177/0263395716644941.

${ }^{86}$ Cunneen, "Postcolonial Perspectives for Criminology," 254.

${ }^{87}$ Paul Jackson, "Security Sector Reform and State Building," Third World Quarterly 32, no. 10

(2011): 1808, https://doi.org/10.1080/01436597.2011.610577.

88 Jackson, 1804.

${ }^{89}$ Aas, “"The Earth Is One,"” 15.
} 
analysing a state's sovereignty, one should consider the variety of the population in a territory, and not rely solely on identifying a single form of control within the state.

Due to globalisation and an ever-growing international system of connection and reliance, ${ }^{90}$ this movement calls for a reshuffling of power $^{91}$ and a more representative distribution of knowledge production throughout the globe to amend asymmetries. ${ }^{92}$ However, for Global South countries, these shifts must be independent of a transnational movement. A transformation of colonial concepts is essential for establishing comprehensive stability within Global South territories. That is, because the foundations of states in the Global South were based on a theoretical idea imported from the North (contract theory), which, at the same time, excluded the participation of entire groups of people (e.g. enslaved Africans, natives). ${ }^{93}$ Such arrangements contributed to long-standing internal instabilities and a crisis of legitimacy, since large groups were and remain removed from the social contract.

A post-colonial application of Southern Criminology reveals that state sovereignty, and its legitimacy for punishing, are only theoretical presumptions in the Global South because they began from an exclusionary starting point. On this view, it is necessary to establish a theory of security and peace that considers and gives voice to the multitude of groups with different shares of power that exist in Southern territories. Consequently, by having all groups heard, seen and considered, there will be room for greater cohesion amongst the entire population of formerly colonised countries, leading them to legitimate a more suitable criminal justice system.

\section{Conclusion}

This essay discussed Roger Matthew's claim suggesting that the most significant import of Southern Criminology was to defy the plea of universalism made by Northern social theories. It started by verifying that Southern Criminology is a political, empirical and theoretical postcolonial movement, that arises from former silenced nations and communities in the Global

\footnotetext{
${ }^{90}$ Aas, 8.

${ }^{91}$ Cunneen, "Postcolonial Perspectives for Criminology," 255-256.

92 Aas, "“The Earth Is One," 8.

${ }^{93}$ Carrington and Hogg, "Deconstructing Criminology's Origin Stories," 188.
} 
South. Next, it described how the name "Global South," besides describing specific geographical locations, also referred to some groups of people physically located in the Global North. Conversely, it stated that the Global North is a metaphor for powerful countries and groups of people whose body of knowledge and way of being was reckoned as the ideal standard of achievement.

While universalism considers the products of northern social science as the standard applicable to the rest of the world, Southern Criminology challenges this. This essay, however, claimed there is an issue with seeing the defiance of universalism as the main import of Southern Criminology. The risk is that scholars could be led to believe that such a problem could be overcome by criminological theories made with knowledge acquired in the Global South by representatives of the Global North, ignoring the perspectives of Southern criminologists themselves.

Challenging this view, this essay claims that the main product of Southern Criminology is to bring the criminogenic consequences of colonisation to light. Such a topic demands that representatives of any place produce criminological knowledge, recognising the harmful effects of colonisation and its connection to how we perceive crime, criminals and social control to this day. This essay concludes by portraying the potentialities of developing such criminological knowledge in central and peripheral nations and highlighting the political capacity of advancing Southern Criminology.

The displayed potentialities were, first, criminologists' theorisation of the South that highlights authoritarian dominance. Second, the rupture of the assumption that countries that performed the worst humanitarian crimes in history, namely coloniser countries, would continue to be seen as the emissaries of criminological knowledge. This essay also highlighted the fact that innovative solutions could be lifted from the experience of the Global South such as specific events and other ancient practices formerly ignored. For Northern countries, besides the undeniable advantages of finding new ideas for dealing with crime, it was argued that the recognition of the harmful effects of colonisation, enabled by the expansion of post-colonial Southern Criminology, helps to explain the over-representation of minorities in the criminal 
justice system. Lastly, this essay defended the fact that Southern Criminology's advancement will enhance the legitimacy and sovereignty of states from the Global South and their criminal justice institutions, by constructively criticising the features of states that are directly connected to colonialism and helping to build a system that conforms better to localities and regional praxis.

\section{Bibliography}

Aas, Katja Franko. “"The Earth Is One but the World Is Not': Criminological Theory and Its Geopolitical Divisions.” Theoretical Criminology 16, no. 1 (2012): 5-20. https://doi.org/10.1177/1362480611433433.

Agozino, Biko. "Imperialism, Crime and Criminology: Towards the Decolonisation of Criminology." Crime, Law and Social Change 41, no. 4 (2004): 343-358. https://doi.org/10.1023/B:CRIS.0000025766.99876.4c.

Bloch, Stefano. "Broken Windows Ideology and the (Mis)Reading of Graffiti." Critical Criminology 28, no. 4 (2020): 703-720. https://doi.org/10.1007/s10612-019-09444-w.

Braithwaite, John. "Rethinking Criminology Through Radical Diversity in Asian Reconciliation.” Asian Journal of Criminology 10, no. 3 (2015): 183-191. https://doi.org/10.1007/s11417-014-9200-z.

Cain, Maureen. "Counter-Colonial Criminology: A Critique of Imperialist Reason by B. Agozino." The Howard Journal of Criminal Justice 46, no. 5 (2007): 534-537. https://doi.org/10.1111/j.1468-2311.2007.00499.x.

Carrington, Kerry. "Book Review: Southern Theory: The Global Dynamics of Knowledge in the Social Sciences by Raewyn Connell.” Journal of Sociology 44, no. 3 (2008): 301308. https://doi.org/10.1177/1440783308092886.

Carrington, Kerry, and Russell Hogg. "Deconstructing Criminology's Origin Stories." Asian Journal of Criminology 12, no. 3 (2017): 181-197. https://doi.org/10.1007/s11417017-9248-7.

Carrington, Kerry, Russell Hogg, and Máximo Sozzo. "Southern Criminology." The British Journal of Criminology 56, no. 1 (2016): 1-20. https://doi.org/10.1093/bjc/azv083.

Codino, Rodrigo. "Por Uma Outra Criminologia do Terceiro Mundo: Perspectivas Da Criminologia Crítica no Sul [For Another Third World Criminology: Perspectives from the South's Critical Criminology]." Revista Liberdades, no. 20 (September/December 2015): 22-35. https://www.ibccrim.org.br/publicacoes/edicoes/462/7428. 
Cunneen, Chris. "Postcolonial Perspectives for Criminology." In What Is Criminology?, edited by Mary Bosworth and Carolyn Hoyle, 249-266. Oxford: Oxford University Press, 2011. https://doi.org/10.1093/acprof:oso/9780199571826.003.0018.

Escobar, Arturo. Encountering Development: The Making and Unmaking of the Third World. Princeton: Princeton University Press, 2011.

Fishwick, Elaine, and Marinella Marmo. "Criminology in Australia: A Global South Perspective." In The Handbook of the History and Philosophy of Criminology, edited by Ruth Ann Triplett, 321-333. Hoboken, NJ: Wiley-Blackwell, 2018. https://doi.org/10.1002/9781119011385.ch19.

Garland, David. The Culture of Control. Oxford: Oxford University Press, 2001.

Green, David A. "Feeding Wolves: Punitiveness and Culture." European Journal of Criminology 6, no. 6 (2009): 517-536. https://doi.org/10.1177/1477370809341227.

Henderson, Willie. "Metaphors, Narrative and 'Truth': South Africa's TRC.” African Affairs 99, no. 396 (2000): 457-465. https://doi.org/10.1093/afraf/99.396.457.

Indermaur, David. "What Can We Do to Engender a More Rational and Less Punitive Crime Policy?” European Journal of Criminal Policy and Research 15, no. 1-2 (2009): 181199. https://doi.org/10.1007/s10610-008-9096-1.

Jackson, Paul. "Security Sector Reform and State Building." Third World Quarterly 32, no. 10 (2011): 1803-1822. https://doi.org/10.1080/01436597.2011.610577.

Lee, Melissa M., Gregor Walter-Drop, and John Wiesel. "Taking the State (Back) Out? Statehood and the Delivery of Collective Goods." Governance 27, no. 4 (2014): 635654. https://doi.org/10.1111/gove.12069.

Liu, Jianhong. "Asian Criminology - Challenges, Opportunities, and Directions." Asian Journal of Criminology 4, no. 1 (2009): 1-9. https://doi.org/10.1007/s11417-0099066-7.

- "Principles of Restorative Justice and Confucian Philosophy in China." Newsletter of the European Forum for Restorative Justice 8, no. 1 (2007): 2-3.

https://www.researchgate.net/publication/285055041_Principles_of_Restorative_Justi ce_and_Confucius_Philosophy_in_China.

Matthews, Roger. "False Starts, Wrong Turns and Dead Ends: Reflections on Recent Developments in Criminology." Critical Criminology 25, no. 4 (2017): 577-591. https://doi.org/10.1007/s10612-017-9372-9.

Mignolo, Walter D. "The Geopolitics of Knowledge and the Colonial Difference." South Atlantic Quarterly 101, no. 1 (2002): 57-96. https://doi.org/10.1215/00382876-101-157.

Mueller, Justin. “Temporality, Sovereignty, and Imperialism: When is Imperialism?” Politics 36, no. 4 (2016): 428-440. https://doi.org/10.1177/0263395716644941.

Pratt, John. Penal Populism. London: Routledge, 2007. 
Simon, Jonathan. "Entitlement to Cruelty: Neo-Liberalism and the Punitive Mentality in the United States." In Crime, Risk and Justice: The Politics of Crime Control in Liberal Democracies, edited by Kevin Stenson and Robert R. Sullivan, 125-143. Cullompton, Devon: Willan Publishing, 2001.

Wacquant, Loïc. "Ordering Insecurity: Social Polarization and the Punitive Upsurge."

Radical Philosophy Review 11, no. 1 (2008): 1-19. https://doi.org/10.5840/radphilrev20081112.

Weber, Barret, and Rob Shields. "The Virtual North: On the Boundaries of Sovereignty." Ethnic and Racial Studies 34, no. 1 (2011): 103-120. https://doi.org/10.1080/01419870.2010.490592.

Weber, Max, H. H. Gerth, C. Wright Mills, and Bryan S. Turner. From Max Weber: Essays in Sociology. London: Routledge, 2009. https://doi.org/10.4324/9780203452196.

Wilson, James Q., and George L. Kelling. "Broken Windows: The Police and Neighborhood Safety." The Atlantic Monthly 249, no. 3 (1982): 29-38.

https://www.semanticscholar.org/paper/BROKEN-WINDOWS\%3A-THE-POLICEAND-NEIGHBOURHOOD-SAFETY-Wilson-

Kelling/afac4ce61a0a68b81964a29efccb3cf4b81f2ff9.

Zaffaroni, Eugenio Raúl. Criminología: Aproximación Desde Un Margen. Bogotá: Editorial Temis S.A., 1988. 